\title{
PENAPISAN ISOLAT BAKTERI Streptococcus spp. SEBAGAI KANDIDAT ANTIGEN DALAM PEMBUATAN VAKSIN, SERTA EFIKASINYA UNTUK PENCEGAHAN PENYAKIT STREPTOCOCCOSIS PADA IKAN NILA, Oreochromis niloticus
}

\author{
Taukhid dan Uni Purwaningsih \\ Balai Riset Perikanan Budidaya Air Tawar \\ Jl. Sempur No. 1, Bogor 16154 \\ E-mail: taukhid_as@yahoo.co.id
}

(Naskah diterima: 22 Agustus 2010; Disetujui publikasi: 21 Maret 2011)

\begin{abstract}
ABSTRAK
Riset dengan tujuan untuk memperoleh isolat kandidat yang imunogenik bagi pembuatan vaksin untuk pengendalian penyakit streptococcosis pada ikan nila telah dilakukan. Karakterisasi dilakukan secara biokimia dan API 20 STREP terhadap 15 isolat bakteri Streptococcus spp. Uji Koch's Postulate kemudian dilakukan untuk mengetahui peran bakteri pada infeksi streptococcosis pada ikan nila. Konfirmasi taksonomis hingga level spesies isolat bakteri S. agalactiae dilakukan dengan teknik Polymerase Chain Reaction (PCR) dengan menggunakan primer spesifik. Uji patogenisitas dilakukan terhadap 6 isolat yang terdiri atas 5 isolat S. agalactiae (N3M, N4M, N14G, N17O, NK1) dan 1 isolat S. iniae (N2O). Hasil penapisan menunjukkan bahwa bakteri S. agalactiae (N4M) memiliki nilai $\mathrm{LD}_{50}$ terkecil, dan nilai terbesar dimiliki oleh bakteri S. iniae (N2O). Isolat bakteri N4M digunakan sebagai sumber antigen dalam pembuatan vaksin anti streptococcosis. Vaksin disiapkan dalam bentuk sel utuh dan diinaktivasi dengan formalin, pemanasan, dan sonikasi. Nilai titer antibodi dan sintasan tertinggi diperoleh pada kelompok ikan yang divaksin dengan formalin killed vaccine dibandingkan dengan teknik inaktivasi lainnya (heat killed vaccine dan sonicated vaccine).
\end{abstract}

KATA KUNCI: penapisan, streptococcosis, vaksin, ikan nila

ABSTRACT: Screening of Streptococcus spp. isolates as an antigen candidate in vaccine development, and its efficacy to prevent streptococcosis on tilapia, Oreochromis niloticus. By: Taukhid and Uni Purwaningsih

The research with the aim to find an immunogenic isolate candidate for vaccine development to prevent streptococcosis on tilapia has been carried out at laboratory scale. Characterization was done using biochemical characterization and API 20 Strep system on 15 Streptococcus spp. bacterial. It was followed by Koch's Postulate to know the role of bacterial isolates in streptococcosis infection in tilapia. Taxonomic confirmation to species level of the bacteria was conducted using Polymerase Chain Reaction (PCR) technique with specific primer set. The pathogenicity test of six selected bacterial isolates consisted of five Streptococcus agalactiae isolates (N3M, N4M, $\mathrm{N} 14 \mathrm{G}, \mathrm{N170}, \mathrm{NK} 1$ ), and one isolate of S. iniae (N2O) was artificially done by infecting the isolates into the tilapia population. The whole cell vaccine was prepared in liquid broth medium, and inactivated by formalin killed, heat killed, and sonicated killed. The results of the screening revealed that $S$. agalactiae (N4M) has the lowest $L D_{50}$ level, and the highest was S. iniae (N2O). Based on the screening protocol, the N4M 
was used as an antigen source in vaccine development, and its efficacy was evaluated accordingly. The highest titre antibody level and survival rate of vaccinated fish was attained from formalin killed vaccine compared to the others (heat killed and sonicated vaccine).

KEYWORDS: screening, streptococcosis, vaccine, tilapia, Oreochromis niloticus

\section{PENDAHULUAN}

Ikan nila merupakan salah satu primadona perikanan budidaya air tawar yang diharapkan mampu meningkatkan produksi perikanan nasional, kesejahteraan masyarakat, serta konsumsi protein hewani asal ikan. Beberapa keunggulan komparatif dan kompetitif yang dimiliki ikan nila, antara lain: laju pertumbuhan yang cepat, toleran terhadap kualitas lingkungan perairan yang ekstrim, siklus reproduksi yang cepat, tekstur daging yang kompak dan berwarna putih sehingga banyak diminati pasar sebagai pemasok protein hewani asal ikan.

Program pemerintah (c.q. Kementerian Kelautan dan Perikanan) menargetkan produksi perikanan meningkat hingga 353\% pada akhir tahun 2014. Realisasi dari program tersebut terutama difokuskan melalui peningkatan produksi dari sub sektor perikanan budidaya, terutama melalui program intensifikasi. Intensifikasi budidaya merupakan upaya peningkatkan produksi biomassa dalam wadah dan media yang terbatas melalui penerapan kepadatan tinggi, pemberian pakan buatan, serta sistem pengelolaan budidaya yang lebih seksama, termasuk upaya pengendalian penyakit. Secara umum, program pengendalian penyakit belum diterapkan sebagai bagian yang terintegrasi dalam budidaya ikan; sehingga apabila terjadi suatu kasus penyakit lebih banyak ditanggapi dengan kepanikan dan kepasrahan. Kecenderungan global terhadap produk perikanan budidaya menuntut persyaratan 4 (empat) sehat, yaitu: (1) sehat lingkungan budidaya, (2) sehat proses produksi, (3) sehat ikan, dan (4) sehat produk. Kunci untuk dapat memenuhi keempat kondisi tersebut adalah penerapan program pengelolaan kesehatan ikan secara konsekuen, terintegrasi, dan ramah lingkungan.

Pembudidayaan ikan nila di danau, waduk, sungai, serta di kolam-kolam telah terbukti sebagai usaha ekonomi rakyat yang potensial dan terus berkembang. Intensifikasi merupakan salah satu alternatif untuk meningkatkan produksi ikan nila secara signifikan. Namun intensifikasi akan mengakibatkan tekanan (stress) yang lebih besar terhadap komoditas ikan yang dibudidayakan, sehingga menjadi lebih rentan terhadap penyakit. Salah satu penyakit infeksius yang semakin sering terjadi pada budidaya ikan nila adalah penyakit streptococciasis yang disebabkan oleh Streptococcus iniae dan S. agalactiae (Yanong \& Floyd, 2002), dan infeksi jenis bakteri tersebut dapat bersifat akut yang mengakibatkan kematian massal (>50\%) dalam tempo 3-7 hari, atau kematian berpola kronik yang persisten selama beberapa minggu. Infeksi Streptococcus spp. pada ikan mengakibatkan penyakit yang disebut "syndrome meningoencephalitis dan panophthalmitis" dengan gejala umum seperti: lemah, warna gelap, hilang nafsu makan, disorientasi atau hilang keseimbangan, uni/bilateral exophthalmia dengan kornea mata berwarna pucat, pendarahan dan luka pada bagian eksternal. Pada organ internal menunjukkan gejala adanya ascites, pembengkakan limpa, ginjal, hati, dan organ dalam lainnya.

Hingga kini belum diketahui jenis bahan kimia/antibiotik yang efektif untuk mengendalikan penyakit streptococcosis pada ikan. Issue global yang sudah mulai berkembang berkenaan dengan penggunaan obat dan antibiotik pada budidaya perikanan, antara lain: (1). Pengaruh penggunaan zat aditif, antibiotik, hormon, desinfektan, dan bahan kimia lain pada proses produksi ikan terhadap lingkungan perairan, diversitas biologi (bio-diversity) atau keaneka ragaman hayati serta kesehatan manusia, (2). Pengaruh akumulasi/residu obat/ antibiotik pada produk perikanan (terutama consumption products) terhadap kesehatan konsumen, dan (3). Berkembangnya resistensi patogen terhadap obat/antibiotik, terutama akibat penggunaan satu jenis antibiotik yang dilakukan berulang-ulang dan kurang terkendali.

Vaksinasi pada perikanan budidaya telah terbukti memberi kontribusi yang sangat signifikan terhadap peningkatan produksi 
perikanan budidaya, terutama industri salmon dan trout di Eropa. Selain vaksin untuk kedua jenis ikan tersebut, beberapa jenis vaksin juga telah beredar secara komersial untuk ikan channel catfish di Amerika, kakap \& kerapu di Eropa, serta amberjack, ekor kuning, tilapia dan Atlantic cod. Saat ini, sedikitnya ada 10 jenis vaksin telah dipasarkan secara umum dan diaplikasikan oleh pembudidaya ikan di Amerika, Eropa, dan Jepang. Keberhasilan program vaksinasi tersebut sangat meyakinkan, hal itu terlihat dari (1) menurunnya tingkat mortalitas ikan budidaya akibat infeksi patogen potensial, (2) menurunnya penggunaan antibiotik pada budidaya ikan, dan (3) menurunnya daya resistensi beberapa jenis patogen terhadap antibiotik.

Teknologi pengendalian penyakit ikan yang efisien, efektif, dan ramah lingkungan merupakan satu-satunya alternatif yang harus dikembangkan untuk mendukung program peningkatan produksi perikanan budidaya. Pengunaan vaksin untuk pencegahan terhadap penyakit potensial pada perikanan budidaya merupakan opsi solusi yang sangat realistis dan prospektif. Riset ini bertujuan untuk memperoleh isolat kandidat serta sediaan antigen yang memiliki potensi imunogenik bagi pembuatan vaksin untuk pengendalian penyakit streptococcosis pada ikan nila.

\section{BAHAN DAN METODE}

\section{Ikan Uji}

Ikan uji yang digunakan adalah ikan nila sebagai inang rentan (susceptible host) terhadap infeksi Streptococcus spp. dengan ukuran \pm 15 gram/ekor. Ikan uji berasal dari populasi homogen dan diasumsikan "specific pathogen free (SPF)" terhadap patogen target berdasarkan hasil diagnosa secara bakteriologis yang dilakukan secara acak terhadap populasi tersebut sebelum proses aklimatisasi.

Pemberian pakan dilakukan secara adlibitum sebanyak 3 kali/hari (pagi, siang, dan sore). Jenis pakan yang digunakan adalah pakan komersial (pellet apung) dengan kadar protein kasar sebesar $\pm 20 \%$.

Penapisan (Screening) Isolat Kandidat

\section{Karakterisasi dan Koch's Postulate}

Penapisan isolat bakteri Streptococcus spp. dilakukan terhadap koleksi isolat yang tersedia di Biological Culture Collection (BCC) milik Laboratorium Kesehatan dan Patologi Ikan, Balai Riset Perikanan Budidaya Air Tawar, serta isolat yang diperoleh dari kasus penyakit streptococcosis pada ikan nila di wilayah Jawa Barat, Jawa Tengah, Jawa Timur, Sulawesi Utara, dan Papua Barat.

Karakterisasi terhadap seluruh isolat bakteri Streptococcus spp. yang akan disertakan dalam proses penapisan awal dilakukan dengan metode uji biokimia yang mengacu pada metode Rancangan Standar Nasional Indonesia (RSNI) "Metode identifikasi bakteri Streptococcus iniae dan $S$. agalactiae pada ikan secara konvensional", API 20 STREP System, serta metode identifikasi bakteri patogen pada ikan menurut Austin \& Austin (2001).

Seluruh isolat yang sudah diketahui secara definitif sebagai Streptococcus spp., terlebih dahulu diuji keabsahannya sebagai patogen penyebab streptococcosis sesuai kaidah Koch's Postulate: (1). Organisme/patogen harus ditemukan pada hewan yang sakit, (2). Organisme/patogen harus bisa diisolasi dari hewan yang sakit, dan dapat ditumbuhkan secara murni, (3). Penyakit harus dapat timbul kembali (reproduced) apabila organisme dari biakan murni diinfeksikan ke hewan sehat yang rentan (healthy susceptible host) $\approx$ individu SPF, dan (4). Organisme/patogen harus dapat direisolasi dari hewan yang diinfeksi secara buatan.

Masing-masing isolat ditumbuhkan pada media Brain Heart Infusion Agar (BHIA) dan diinkubasikan pada suhu $28^{\circ} \mathrm{C}$ selama 24 jam. Sebanyak satu Ose koloni bakteri dilarutkan dalam $1 \mathrm{~mL}$ media BHIA, sehingga "diasumsikan" bahwa setiap larutan bakteri tersebut memiliki konsentrasi yang sama. Bakteri diinfeksikan ke ikan uji melalui penyuntikan secara intra peritoneal (IP) sebanyak $0,1 \mathrm{~mL} /$ ekor dari stok kultur mengandung $10^{8} \mathrm{cfu} / \mathrm{mL}$. Jumlah ikan uji yang digunakan untuk masingmasing jenis isolat adalah 5 ekor.

Ikan uji yang menunjukkan tingkah laku dan gejala klinis spesifik $(\approx$ diduga kuat akibat infeksi Streptococcus spp.) segera direisolasi pada media BHIA, dan karakterisasi ulang secara bakteriologis untuk memastikan bahwa isolat bakteri tersebut merupakan isolat bakteri Streptococcus spp. yang diinfeksikan. Uji Koch's Postulate terhadap masing-masing isolat bakteri dilakukan sebanyak 2 (dua) kali dengan jumlah ikan uji dan prosedur yang sama. 


\section{Penapisan isolat kandidat}

Penapisan dilakukan dengan teknik dan prosedur yang sama dalam uji Koch's Postulate. Ke-15 isolat yang sudah definitif sebagai Streptococcus spp. hasil reisolasi dan rekarakterisasi segera dibiakkan dalam media Brain Heart Infusion Broth (BHIB) dan diinkubasi pada suhu $28^{\circ} \mathrm{C}$ selama 24 jam. Bakteri dari media biakan cair tersebut diencerkan 10 kali dalam media BHIB, untuk selanjutnya diinfeksikan ke populasi ikan uji melalui penyuntikan IP sebanyak $0,1 \mathrm{~mL} /$ ekor. Sebanyak 15 ekor ikan uji digunakan untuk setiap isolat bakteri yang disertakan dalam proses penapisan ini.

Pengamatan terhadap tingkah laku, gejala klinis, dan mortalitas ikan uji dilakukan setiap hari hingga akhir proses penapisan yang ditentukan pada hari ke-14 pasca proses infeksi. Reisolasi dan rekarakterisasi dilakukan pada masing-masing kelompok terhadap minimal satu ekor ikan yang sedang sekarat (moribund fish). Seperti halnya pada uji Koch's Postulate, ikan yang menunjukkan tingkah laku dan gejala klinis spesifik ( $\approx$ diduga kuat akibat infeksi Streptococcus spp.) segera direisolasi pada media BHIA, dan karakterisasi ulang secara bakteriologis untuk memastikan bahwa isolat bakteri tersebut merupakan isolat bakteri Streptococcus spp. yang diinfeksikan.

Proses penapisan ini digunakan untuk memilih isolat-isolat bakteri yang akan disertakan dalam proses penentuan isolat kandidat sebagai sumber antigen dalam pembuatan vaksin anti-streptococcosis. Evaluasi hasil proses penapisan dibangun berdasarkan 2 (dua) kriteria, yaitu: (1). Dalam tempo 7 (tujuh) hari pertama mengakibatkan kematian ikan uji lebih dari 75\%, dan (2). Apabila lebih dari satu isolat Streptococcus spp. berasal dari individu ikan yang sama, maka dipilih satu isolat sebagai representasi dari individu tersebut.

\section{Penentuan Isolat Kandidat (Uji Patogenisitas)}

Penentuan isolat kandidat pada riset ini dilakukan melalui pendekatan nilai patogenisitas isolat bakteri Streptococcus spp. yang dihitung berdasarkan nilai dosis/ konsentrasi bakteri yang mengakibatkan kematian sebanyak $50 \%$ dari total populasi selama periode tertentu $\left(\mathrm{LD}_{50}\right)$ dari masingmasing isolat terhadap ikan uji. Hasil evaluasi proses penapisan, terpilih 6 (enam) isolat bakteri Streptococcus spp. untuk disertakan pada proses selanjutnya.

Penghitungan konsentrasi bakteri dari hasil biakan dalam media BHIB dihitung dengan teknik standar Total Plate Count (TPC). Penyiapan bakteri dalam proses uji tantang dilakukan dalam media BHIB, dan pengenceran untuk mendapatkan konsentrasi bakteri sesuai dengan perlakuan juga dilakukan dengan media BHIB steril.

Keenam isolat bakteri Streptococcus spp. yang disertakan pada proses uji patogenisitas adalah isolat: (1). N2O, (2). N3M, (3). N4M, (4). N14G, (5). N1 70, dan (6). NK1. Uji patogenisitas dilakukan dengan infeksi buatan melalui penyuntikan secara IP sebanyak $0,1 \mathrm{~mL} /$ ekor dengan konsentrasi bakteri yang berbeda sebagai perlakuan, dan masing-masing kelompok perlakuan dilakukan pengulangan sebanyak 3 (tiga) kali. Konsentrasi bakteri yang diterapkan pada pengujian ini adalah:
A. $1,75 \times 10^{7} \mathrm{cfu} /$ ekor
B. $1,75 \times 10^{5} \mathrm{cfu} / \mathrm{ekor}$
C. $1,75 \times 10^{3} \mathrm{cfu}$ /ekor
D. BHIB steril sebagai kontrol

Selama proses uji patogenisitas yang berlangsung selama 14 (empat belas) hari, ikan dipelihara dalam bak plastik yang diisi air sebanyak 80 liter, dilengkapi pengudaraan (aerasi), dan diisi ikan uji sebanyak 20 ekor/ wadah. Selama proses pengujian tidak dilakukan penggantian air, dan pemberian pakan dilakukan secara adlibitum sebanyak 3 kali/ hari (pagi, siang dan sore).

Pengamatan terhadap tingkah laku, gejala klinis dan mortalitas ikan uji dilakukan setiap hari hingga akhir proses uji patogenisitas yang ditentukan pada hari ke-14 pasca proses infeksi. Reisolasi dan rekarakterisasi dilakukan pada masing-masing kelompok terhadap minimal satu ekor ikan yang sedang sekarat (moribund fish).

\section{Preparasi Vaksin}

Isolat bakteri yang digunakan sebagai sumber antigen adalah bakteri Streptococcus agalactiae dengan kode isolat N4M. Pembiakan bakteri dilakukan dalam media cair Brain Heart Infusion Broth (BHIB) dengan prosedur standar yang dikembangkan secara internal dan divalidasi untuk memperoleh hasil yang 
konsisten. Kuantifikasi untuk mengetahui konsentrasi larutan baku (stock solution) vaksin dilakukan melalui konversi hasil TPC.

Biakan bakteri diinkubasi pada suhu $28^{\circ} \mathrm{C}$ selama 24 jam, kemudian panenan bakteri diinaktifasi dengan 3 (tiga) teknik, yaitu: (1). Penggunaan larutan formalin $0,3 \%$ selama 60 menit (formalin killed), (2). Pemanasan pada suhu $100^{\circ} \mathrm{C}$ selama 60 menit (heat killed), dan (3). Pemecahan sel bakteri melalui proses sonikasi pada amplitude standar selama $4 \mathrm{x}$ 15 detik (sonicated killed). Selanjutnya, larutan baku vaksin dicuci dengan larutan saline $(0,85 \%)$ steril sebanyak 2 kali melalui proses sentrifugasi pada $6.000 \mathrm{rpm}$. Sediaan vaksin dalam bentuk sel utuh (whole cell vaccine) selanjutnya disimpan pada suhu $\pm 4^{\circ} \mathrm{C}$ dan siap untuk digunakan.

\section{Viabilitas Vaksin}

Secara homogen, sebanyak $3 \times 0,2 \mathrm{~mL}$ sediaan vaksin ditumbuhkan pada media BHIA dan diinkubasi pada suhu $28^{\circ} \mathrm{C}$ selama $2 \times 24$ jam untuk mengetahui sterilitas dan viabilitas (kemampuan untuk tumbuh dan berkembang) bakteri yang digunakan dalam pembuatan vaksin.

\section{Potensi Imunogenisitas}

Pengujian imunogenisitas dilakukan terhadap ketiga teknik inaktivasi vaksin, yaitu (1). formalin killed, (2). heat killed, (3). sonicated killed, dan (4) larutan BHIB steril sebagai kontrol. Populasi ikan nila SPF dengan ukuran \pm 15 gram/ekor digunakan sebagai hewan uji. Sebanyak $0,1 \mathrm{~mL} /$ ekor larutan vaksin dengan konsentrasi $1,75 \times 10^{6} \mathrm{cfu} / \mathrm{mL}$ diberikan melalui penyuntikan secara IP.

Selama periode induksi kekebalan yang ditentukan selama 4 (empat) minggu pasca vaksinasi, ikan uji dipelihara secara pooling dari masing-masing kelompok perlakuan dalam wadah berupa fiber glass volume 200 liter yang diisi ikan sebanyak 500 ekor. Ikan uji diberi pakan secara adlibitum sebanyak 3 kali/ hari (pagi, siang, dan sore). Selama periode induksi kekebalan, suhu air dipertahankan pada kisaran $27-29^{\circ} \mathrm{C}$ dan penggantian air dilakukan setiap hari melalui penyifonan sebanyak $50 \%$ dari total volume.

Pada minggu ke-IV pasca pemberian vaksin, dilakukan uji tantang terhadap ikan uji dari masing-masing kelompok perlakuan. Uji tantang secara eksperimental, dilakukan dalam akuarium ukuran $30 \mathrm{~cm} \times 40 \mathrm{~cm} \times 35 \mathrm{~cm}$ diisi air sebanyak 40 liter dengan kepadatan 20 ekor/wadah. Masing-masing kelompok perlakukan dilakukan pengulangan sebanyak 3 kali. Uji tantang dilakukan melalui teknik penyuntikan bakteri aktif isolat $S$. agalactiae kode isolat N4M secara IP pada dosis $\mathrm{LD}_{50} \approx 10^{3}$ cfu/ekor, dan berlangsung selama 14 (empat belas) hari.

Pengamatan terhadap tingkah laku, gejala klinis dan mortalitas ikan uji dilakukan setiap hari hingga akhir berlangsungnya kegiatan riset. Pengamatan secara intensif terhadap parameter-parameter tersebut terutama dilakukan selama proses uji tantang. Pada periode uji tantang, dilakukan pengambilan sampel selektif terhadap individu yang menunjukkan tingkah laku dan/atau gejala klinis spesifik, minimal sebanyak satu ekor dari masing-masing kelompok perlakuan untuk diagnosa/identifikasi patogen target.

Potensi imunogenisitas (efektivitas vaksin) diukur melalui 2 (dua) indikator, yaitu nilai titer antibodi dan sintasan ikan uji selama proses uji tantang. Pengukuran titer antibodi (in vitro) dilakukan secara pooling dari masing-masing kelompok perlakuan, dan dilakukan secara berkala setiap minggu sejak hari ke-0 hingga akhir penelitian. Pengambilan darah dilakukan dengan alat suntik volume $1,0 \mathrm{~mL}$ melalui dorsal aorta puncture, untuk selanjutnya diproses secara serologis hingga diperoleh serum darah ikan yang relatif murni.

Pengukuran/pengamatan titer antibodi dilakukan secara langsung dengan teknik direct agglutination test menurut metode yang dikembangkan oleh Roberson (1990), yaitu mereaksikan antara serum darah ikan uji dengan bakteri S. agalactiae aktif. Kuantifikasi titer antibodi dilakukan melalui pengenceran serum darah ikan uji secara seri dalam 96-well plate.

Level proteksi relatif diukur melalui nilai sintasan ikan uji pada akhir periode uji tantang. Pengamatan juga dilakukan terhadap tingkah laku dan gejala klinis selama proses uji tantang. Efikasi vaksin diukur dengan nilai persentase sintasan relatif (Relative percent survival/RPS) yang dihitung dengan formula:

$$
\text { RPS }=1-\frac{\% \text { mortalitas ikan yang divaksin }}{\% \text { mortalitas ikan kontrol }} \times 100
$$


Parameter-parameter yang dielaborasi selama berlangsungnya riset, dianalisis secara deskriptif dan/atau statistik sesuai dengan rancangan percobaan yang diterapkan, serta jenis informasi/data yang diperoleh.

\section{HASIL DAN BAHASAN}

\section{Hasil}

Isolat bakteri yang diisolasi dari ikan sakit pada saat terjadi kasus penyakit pada budidaya ikan nila di beberapa wilayah di Jawa Barat, Jawa Tengah, Jawa Timur, Sulawesi Utara, dan Papua Barat terkumpul sebanyak 55 (lima puluh lima) isolat bakteri. Hasil karakterisasi dan/atau identifikasi secara biokimia terhadap 55 isolat bakteri yang diduga sebagai Streptococcus spp., diperoleh sebanyak 15 (lima belas) isolat yang secara definitif adalah bakteri Streptococcus spp. Hasil karakterisasi secara biokimia menurut Rancangan Standar Nasional Indonesia (RSNI) "Metode identifikasi bakteri Streptococcus iniae dan S. agalactiae pada ikan secara konvensional" serta API 20 STREP System terhadap kelima belas isolat bakteri tersebut selengkapnya disajikan pada Tabel 1.

Berdasarkan hasil karakterisasi sebagaimana tercantum pada Tabel 1 , apabila mengacu pada metode RSNI maka sebanyak 12 isolat (80\%) adalah S. agalactiae dan 3 isolat (20\%) adalah S. iniae. Konfirmasi taksonomis hingga level jenis/spesies isolat bakteri $S$. agalactiae yang disertakan pada proses uji tantang juga dilakukan melalui teknik Polymerase Chain Reaction (PCR) dengan

Tabel 1. Hasil karakterisasi biokimia isolat bakteri Streptococcus spp. yang disertakan dalam proses penapisan awal melalui metode Koch's postulate.

Table 1. The result of biochemical characterization from Streptococcus spp. isolates in first screening process using koch's postulate method

\begin{tabular}{|c|c|c|c|c|c|c|c|c|c|c|c|c|c|}
\hline \multirow[b]{2}{*}{$\begin{array}{l}\text { Kode } \\
\text { isolat }\end{array}$} & \multicolumn{13}{|c|}{ Karakter } \\
\hline & 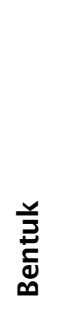 & $\begin{array}{l}\frac{E}{\pi} \\
\text { ज़ }\end{array}$ & 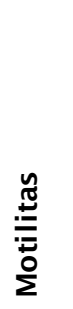 & $\begin{array}{l}\frac{y}{y} \\
\frac{v}{0} \\
\frac{0}{n} \\
\frac{y}{0}\end{array}$ & 芒 & 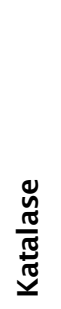 & $\begin{array}{l}\frac{n}{\pi} \\
\stackrel{0}{n} \\
\frac{0}{n}\end{array}$ & 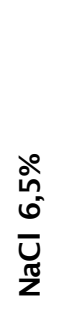 & 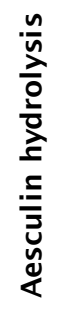 & 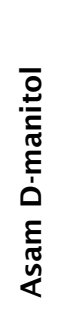 & 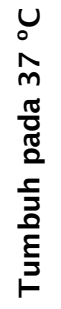 & $\begin{array}{l}\frac{n}{n} \\
\frac{\bar{n}}{0} \\
\frac{\varepsilon}{ \pm} \\
\pm\end{array}$ & 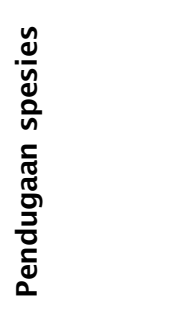 \\
\hline $\mathrm{N} 2 \mathrm{M}$ & CC & + & $\mathrm{nm}$ & - & $\mathrm{F}$ & - & - & + & + & + & + & ß & S. iniae \\
\hline $\mathrm{N} 2 \mathrm{O}$ & CC & + & $\mathrm{nm}$ & - & $\mathrm{F}$ & - & - & + & + & + & + & B & S. iniae \\
\hline N3M & CC & + & $\mathrm{nm}$ & - & $\mathrm{F}$ & - & - & + & - & - & + & - & S. agalactiae \\
\hline N3G & CC & + & $\mathrm{nm}$ & - & $\mathrm{F}$ & - & - & + & - & - & + & - & S. agalactiae \\
\hline N4M & CC & + & $\mathrm{nm}$ & - & $F$ & - & - & + & - & - & + & - & S. agalactiae \\
\hline N4O & CC & + & $\mathrm{nm}$ & - & $F$ & - & - & + & - & - & + & - & S. agalactiae \\
\hline N4G & CC & + & $\mathrm{nm}$ & - & $\mathrm{F}$ & - & - & + & - & - & + & - & S. agalactiae \\
\hline $\mathrm{N} 14 \mathrm{M}$ & CC & + & $\mathrm{nm}$ & - & $\mathrm{F}$ & - & - & + & - & - & + & - & S. agalactiae \\
\hline $\mathrm{N} 140$ & CC & + & $\mathrm{nm}$ & - & $\mathrm{F}$ & - & - & + & - & - & + & - & S. agalactiae \\
\hline N14G & CC & + & $\mathrm{nm}$ & - & $\mathrm{F}$ & - & - & + & - & - & + & - & S. agalactiae \\
\hline $\mathrm{N} 17 \mathrm{M}$ & CC & + & $\mathrm{nm}$ & - & $\mathrm{F}$ & - & - & + & - & - & + & - & S. agalactiae \\
\hline N17O & CC & + & $\mathrm{nm}$ & - & $\mathrm{F}$ & - & - & + & - & - & + & - & S. agalactiae \\
\hline N7TO & CC & + & $\mathrm{nm}$ & - & $F$ & - & - & + & - & - & + & B & S. iniae \\
\hline NK1 & CC & + & $\mathrm{nm}$ & - & $\mathrm{F}$ & - & - & + & + & + & + & - & S. agalactiae \\
\hline NY & CC & + & $\mathrm{nm}$ & - & $\mathrm{F}$ & - & - & + & - & - & + & - & S. agalactiae \\
\hline
\end{tabular}

Keterangan (Note): $\mathrm{cc}=$ coccus, $\mathrm{nm}=$ non motile, $\mathrm{F}=$ fermentative 
menggunakan primer spesifik. Hasil konfirmasi tersebut memberikan hasil positif seperti terlihat pada Gambar 1.

Hasil isolasi bakteri Streptococcus spp. dari 20 ekor ikan nila uji yang diambil secara acak menunjukkan hasil negatif, demikian pula dengan hasil pengamatan secara mikroskopis terhadap keberadaan infestasi parasit. Representasi dari sampel yang diamati mengindikasikan bahwa populasi ikan uji telah memenuhi persyaratan sebagai populasi ikan yang sehat dan dapat diasumsikan SPF terhadap infeksi Streptococcus spp.

Pengujian melalui kaidah Koch's Postulat untuk membuktikan bahwa kelima belas isolat yang tersaring pada penapisan awal memiliki potensi patogenik terhadap ikan nila, menunjukkan bahwa seluruh koleksi isolat tersebut mengakibatkan tingkah laku, gejala klinis, dan kematian terhadap ikan uji; bahkan sebagian besar di antaranya bersifat akut. Gejala klinis yang teramati sangat nyata pada seluruh ikan uji seperti lemah, warna gelap, hilang nafsu makan, disorientasi atau hilang keseimbangan, dan uni/bilateral exophthalmia dengan kornea mata berwarna pucat. Tampilan dari gejala-gejala klinis tersebut dapat dilihat pada Gambar 2 sampai 5.

Berdasarkan kriteria yang telah dibangun dalam evaluasi penapisan awal, maka pada penapisan berikutnya diperoleh 6 (enam) isolat yaitu: (1). N2O, (2). N3M, (3). N4M, (4). N14G, (5). N170, dan (6). NK1 yang disertakan pada proses uji patogenisitas. Rataan mortalitas kumulatif ikan selama proses uji patogenisitas dari keenam isolat bakteri Streptococcus spp., yang terdiri atas 5 isolat bakteri S. agalactiae dan 1 isolat bakteri $S$. iniae selengkapnya disajikan pada Gambar 6 sampai 11 .

Pengamatan terjadinya kematian pada ikan uji pasca infeksi buatan, pada hari pertama dilakukan setiap 8 jam sekali; dan untuk hari berikutnya dilakukan pada selang 24 jam. Pada Gambar Gambar 6 sampai 11 terlihat bahwa hampir seluruh isolat bakteri mampu mengakibatkan kematian sejak hari pertama untuk ketiga konsentrasi bakteri yang diuji; kecuali untuk isolat NK1 yang hanya terjadi pada konsentrasi bakteri $10^{7} \mathrm{cfu} /$ ekor ikan. Mulai hari ke-2 hingga hari ke-10 terjadi kematian yang sporadis untuk masing-masing isolat dan konsentrasi bakteri, dan untuk individu yang bertahan hidup hingga hari ke-14 umumnya mengalami penyembuhan dan bertahan hidup hingga berminggu-minggu kemudian.

Berdasarkan nilai rataan persen mortalitas kumulatif yang diperoleh selama proses uji patogenisitas, nilai $\mathrm{LD}_{50}$ dianalisis dengan regresi linier sederhana untuk memperoleh formulasi matematis $\mathrm{LD}_{50}$ dari masing-masing

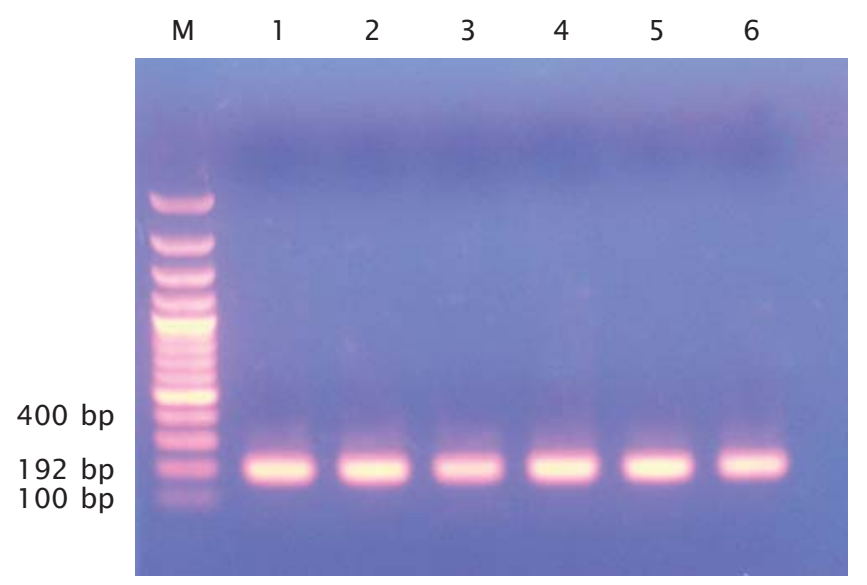

Gambar 1. Profil produk Polymerase Chain Reaction (PCR) DNA bakteri Streptococcus agalactiae (192 bp). (M=100 bp DNA ladder, 1= isolat N3M, 2= isolat $\mathrm{N} 4 \mathrm{M}, 3=$ isolat $\mathrm{N} 4 \mathrm{O}, 4=$ isolat N14G, 5= isolat N1 70, dan 6= isolat NK1)

Figure 1. Product Profile of Polymerase Chain Reaction (PCR) DNA bacteria Streptococcus agalactiae (192 bp). (M=100 bp DNA ladder, $1=$ isolate N3M, $2=$ isolate $N 4 M, 3=$ isolate $N 4 M, 4=$ isolate $N 14 G, 5=$ isolate $N 170$, and $6=$ isolate $N K 1$ ) 

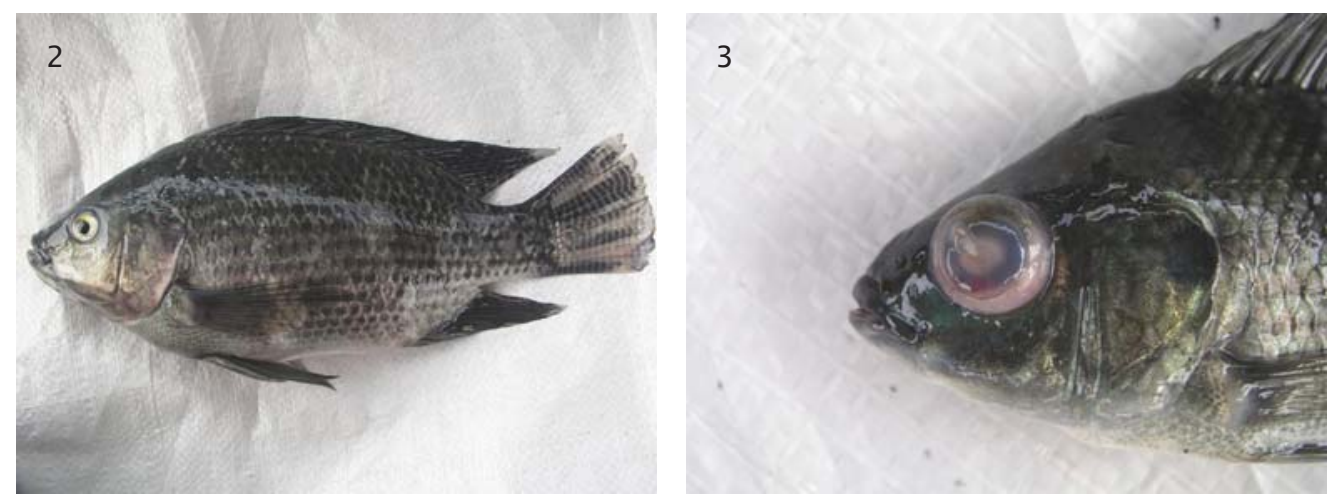

Gambar 2 \& 3. Gejala klinis ikan nila yang diinfeksi bakteri Streptococcus agalactiae secara buatan, warna tubuh gelap (Gambar 2), dan satu sisi mata menonjol/unilateral exophthalmia dengan kornea mata berwarna pucat (Gambar 3)

Figure 2 \& 3. Clinical signs of nile fish that was injected with artificial infection of Streptococcus agalactiae, the whole body becomes dark (figure 2) and unilateral exopthalmia with pale cornea (figure 3)
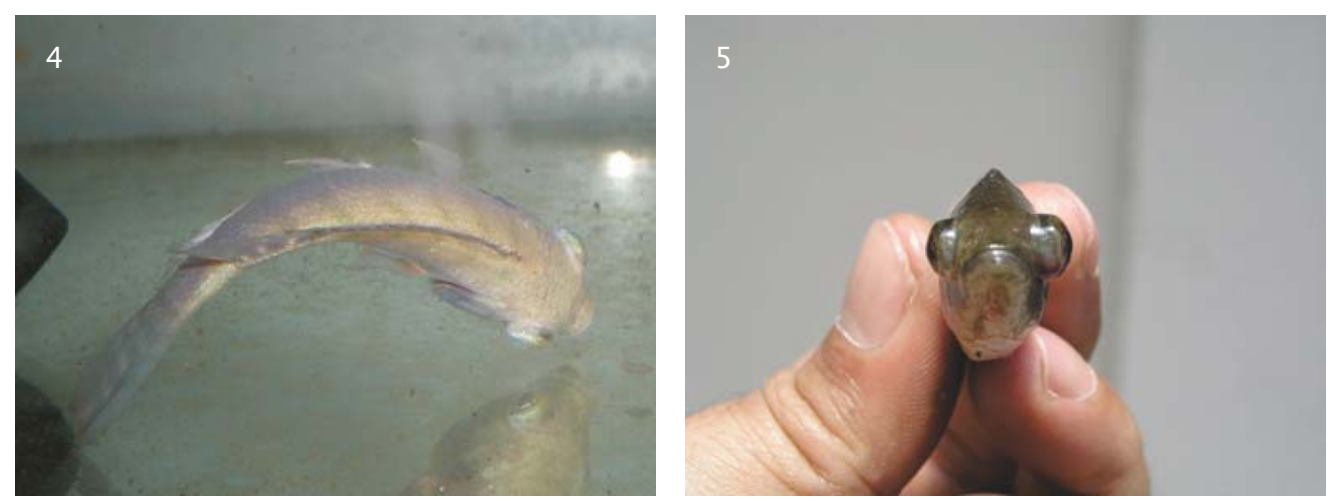

Gambar 4 \& 5. Gejala klinis ikan nila yang diinfeksi bakteri Streptococcus agalactiae secara buatan, disorientasi/hilang keseimbangan (Gambar 4) dan dua sisi mata menonjol/bilateral exophthalmia (Gambar 5)

Figure 4 \& 5 . Clinical signs of nile fish that was injected with artificial infection of Streptococcus agalactiae, disorientation/loss balancing (Figure 4) and bilateral exopthalmia (Figure 5)

isolat bakteri. Formulasi matematis dari masingmasing isolat bakteri selengkapnya disajikan pada Tabel 2. Pada Tabel 2 terlihat bahwa nilai $\mathrm{LD}_{50}$ paling rendah dimiliki oleh bakteri $S$. agalactiae dengan kode isolate N4M yaitu sebesar $6,44 \times 10^{2} \mathrm{cfu}$, dan nilai $\mathrm{LD}_{50}$ terbesar dimiliki oleh bakteri $S$. iniae dengan kode isolat $\mathrm{N} 2 \mathrm{O}$ yaitu sebesar $8,3 \times 10^{5} \mathrm{cfu}$. Pemilihan kandidat isolat bakteri Streptococcus spp. yang digunakan pada riset ini didasarkan pada pendekatan patogenisitas, oleh karena itu isolat bakteri N4M digunakan sebagai sumber antigen dalam pembuatan vaksin anti streptococcosis.

Nilai titer antibodi dalam serum darah ikan uji yang diberi vaksin melalui penyuntikan dengan sediaan vaksin yang diinaktivasi dengan teknik yang berbeda memperlihatkan bahwa pada kelompok ikan uji yang diberi vaksin yang diinaktivasi dengan formalin memberikan nilai titer antibodi yang relatif lebih tinggi dibandingkan dengan teknik 


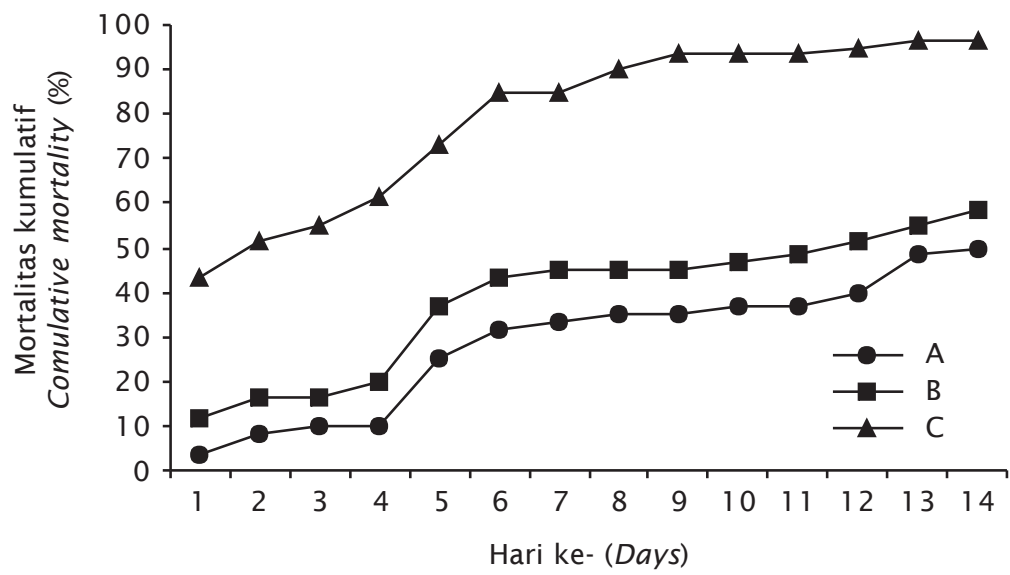

Gambar6. Rataan persen mortalitas kumulatif ikan uji yang diinfeksi bakteri Streptococcus iniae isolat $\mathrm{N} 2 \mathrm{O}$ pada konsentrasi bakterin yang berbeda $\left(A=10^{3} \mathrm{cfu} /\right.$ ekor, $B=10^{5} \mathrm{cfu} /$ ekor, dan $\mathrm{C}=10^{7} \mathrm{cfu} / \mathrm{ekor}$ )

Figure 6. Percentage average of total mortality of sampled fish infected with Streptococcus iniae code N2O in different concentrations $\left(A=10^{3} \mathrm{cfu} / \mathrm{sample}, B=10^{5} \mathrm{cfu} /\right.$ sample, and $\mathrm{C}=10^{7} \mathrm{cfu} /$ sample)

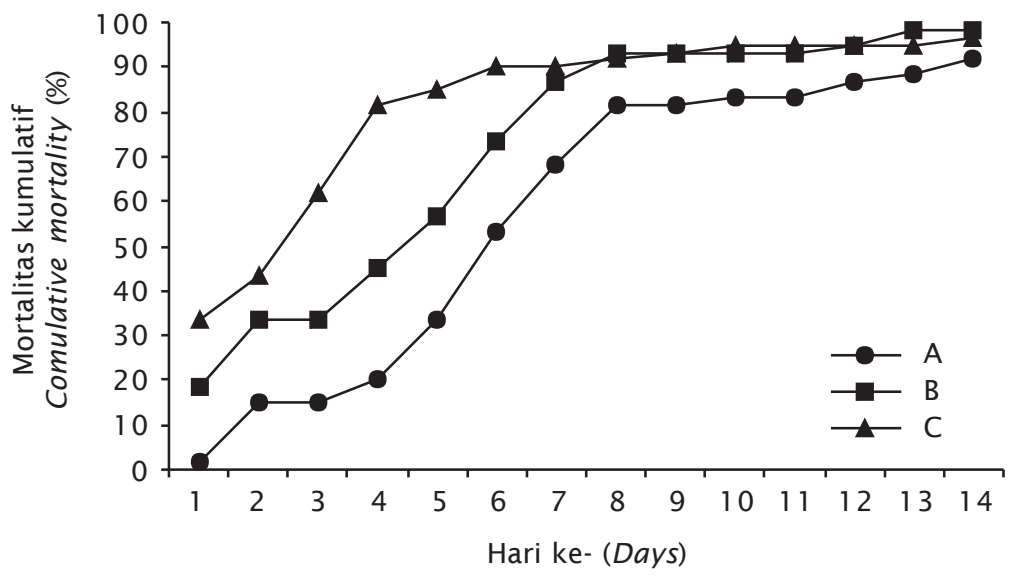

Gambar 7. Rataan persen mortalitas kumulatif ikan uji yang diinfeksi bakteri Streptococcus agalactiae isolat N3M pada konsentrasi bakterin yang berbeda $\left(A=10^{3} \mathrm{cfu} /\right.$ ekor, $B=10^{5} \mathrm{cfu} /$ ekor, dan $\mathrm{C}=10^{7} \mathrm{cfu} / \mathrm{ekor}$ )

Figure 7. Percentage average of total mortality of sampled fish infected with Streptococcus agalactiae code N3M in different concentrations $\left(A=10^{3} \mathrm{cfu} /\right.$ sample, $B=10^{5} \mathrm{cfu} /$ sample, and $C=$ $\left.10^{7} \mathrm{cfu} / \mathrm{sample}\right)$ 


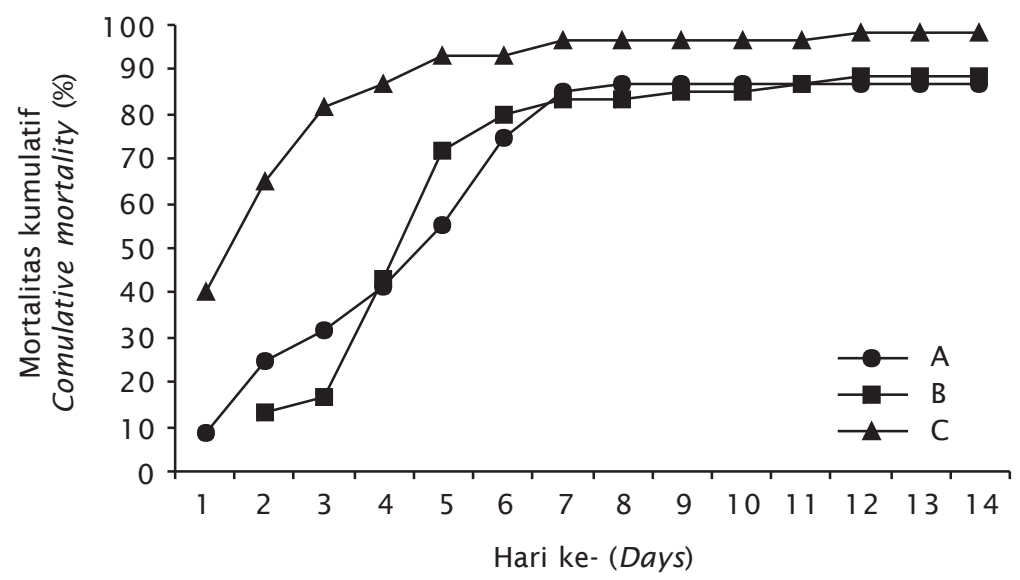

Gambar 8. Rataan persen mortalitas kumulatif ikan uji yang diinfeksi bakteri Streptococcus agalactiae isolat N4M pada konsentrasi bakterin yang berbeda $\left(A=10^{3} \mathrm{cfu} / \mathrm{ekor}, \mathrm{B}=10^{5} \mathrm{cfu} / \mathrm{ekor}\right.$, dan $\mathrm{C}=10^{7} \mathrm{cfu}$ /ekor)

Figure 8. Percentage average of total mortality of sampled fish infected with Streptococcus agalactiae code N4M in different concentrations ( $A=10^{3} \mathrm{cfu} / \mathrm{sample}, B=10^{5} \mathrm{cfu} / \mathrm{sample}$, and $C=10^{7} \mathrm{cfu} /$ sample)

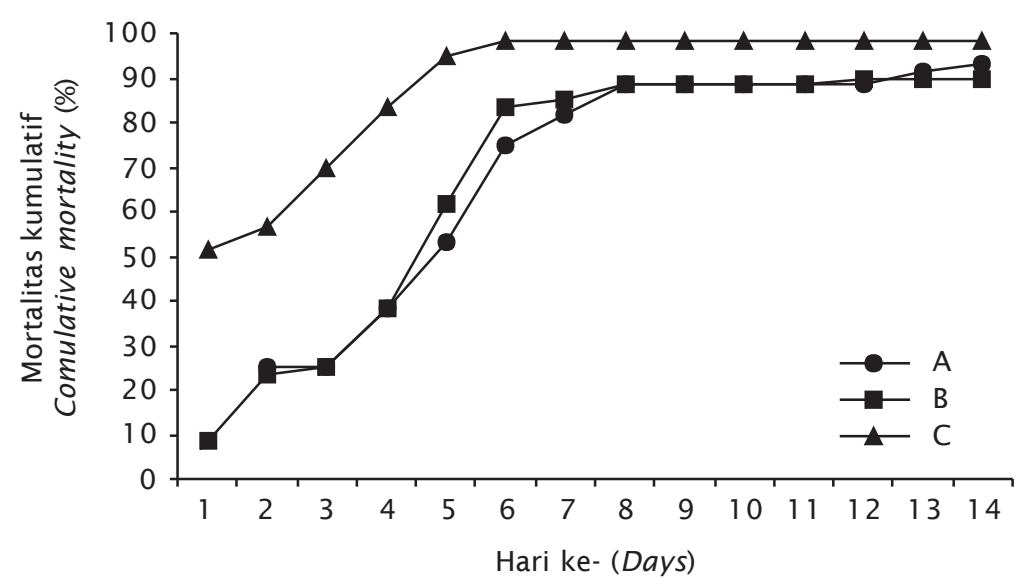

Gambar 9. Rataan persen mortalitas kumulatif ikan uji yang diinfeksi bakteri Streptococcus agalactiae isolat N14G pada konsentrasi bakterin yang berbeda $\left(A=10^{3} \mathrm{cfu} /\right.$ ekor, $B=10^{5} \mathrm{cfu} /$ ekor, dan $\mathrm{C}=10^{7} \mathrm{cfu} /$ ekor)

Figure 9. Percentage average of total mortality of sampled fish infected with Streptococcus agalactiae code N14G in different concentrations ( $A=10^{3} \mathrm{cfu} / \mathrm{sample}, B=10^{5} \mathrm{cfu} /$ sample, and $C=10^{7} \mathrm{cfu} /$ sample) 


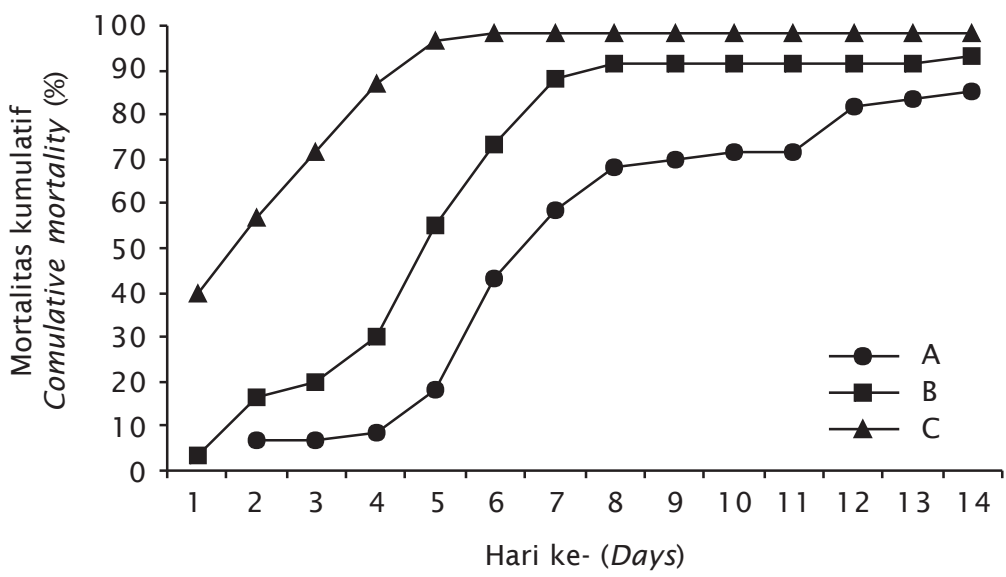

Gambar 10. Rataan persen mortalitas kumulatif ikan uji yang diinfeksi bakteri Streptococcus agalactiae isolat N170 pada konsentrasi bakterin yang berbeda $\left(A=10^{3} \mathrm{cfu} /\right.$ ekor, $B=10^{5}$ cfu/ekor, dan $\mathrm{C}=10^{7} \mathrm{cfu} /$ ekor)

Figure 10. Percentage average of total mortality of sampled fish infected with Streptococcus agalactiae code N17O in different concentrations $\left(A=10^{3} \mathrm{cfu} /\right.$ sample, $B=10^{5} \mathrm{cfu} /$ sample, and $\mathrm{C}=10^{7} \mathrm{cfu} /$ sample)

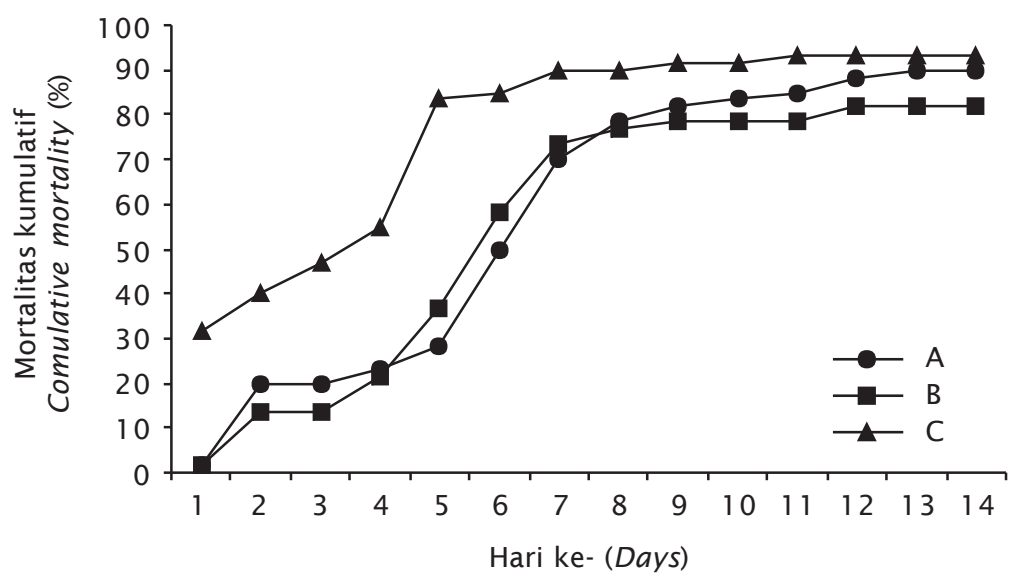

Gambar 11. Rataan persen mortalitas kumulatif ikan uji yang diinfeksi bakteri Streptococcus agalactiae isolat NK1 pada konsentrasi bakterin yang berbeda $\left(A=10^{3} \mathrm{cfu} /\right.$ ekor, $B=10^{5}$ cfu/ekor, dan $\mathrm{C}=10^{7} \mathrm{cfu} /$ ekor)

Figure 11. Percentage average of total mortality of sampled fish infected with Streptococcus agalactiae code NK1 in different concentrations $\left(A=10^{3} \mathrm{cfu} /\right.$ sample, $B=10^{5} \mathrm{cfu}$ ) sample, and $\mathrm{C}=10^{7} \mathrm{cfu} /$ sample) 
Tabel 2. Formulasi dan nilai $\mathrm{LD}_{50}$ dari 6 isolat bakteri Streptococcus spp. yang dihitung melalui analisis regreri linier sederhana

Table 2. The formulation and $L D_{50}$ from 6 Streptococcus spp isolates calculated from a simple analysis of regression linier

\begin{tabular}{lccc}
\hline \multicolumn{1}{c}{ Jenis bakteri } & Kode isolat & Formula nilai LD50 & Nilai LD50 \\
\hline S. iniae & $\mathrm{N} 2 \mathrm{O}$ & $\mathrm{Y}=6.224+7.396 \mathrm{X}$ & $8.3 \times 10^{5} \mathrm{cfu}$ \\
S. agalactiae & $\mathrm{N} 3 \mathrm{M}$ & $\mathrm{Y}=-9.368+12.9127 \mathrm{X}$ & $3.96 \times 10^{4} \mathrm{cfu}$ \\
S. agalactiae & $\mathrm{N} 4 \mathrm{M}$ & $\mathrm{Y}=23.065+9.5877 \mathrm{X}$ & $6.44 \times 10^{2} \mathrm{cfu}$ \\
S. agalactiae & $\mathrm{N} 14 \mathrm{C}$ & $\mathrm{Y}=15.4062+10.4127 \mathrm{X}$ & $2.1 \times 10^{3} \mathrm{cfu}$ \\
S. agalactiae & $\mathrm{N} 170$ & $\mathrm{Y}=-45.9666+19.5753 \mathrm{X}$ & $7.9873 \times 10^{4} \mathrm{cfu}$ \\
S. agalactiae & $\mathrm{NK} 1$ & $\mathrm{Y}=-22.6423+13.7502 \mathrm{X}$ & $1.9187 \times 10^{5} \mathrm{cfu}$ \\
\hline
\end{tabular}

inaktivasi lainnya. Nilai-nilai tersebut selengkapnya dapat dilihat pada Tabel 3.

Rataan persen sintasan ikan pasca uji tantang terhadap isolat bakteri homolog $(S$. agalactiae isolat N4M) menunjukkan bahwa vaksin yang diinaktivasi dengan formalin juga memberikan level proteksi yang relatif lebih baik dibandingkan dengan teknik inaktivasi lainnya. Nilai persen sintasan ikan uji dari masing-masing kelompok perlakuan selengkapnya dapat dilihat pada Tabel 4. Dari Tabel 3 dan 4 mengisyaratkan bahwa teknik inaktivasi sediaan vaksin dengan formalin $3 \%$ memberikan level proteksi yang lebih baik

Tabel 3. Nilai kualitatif titer antibodi serum darah ikan uji selama proses induksi kekebalan spesifik terhadap Streptococcus agalactiae

Table 3. Qualitative values of antibody titre from fish blood during induction specific immunity responses to Streptococcus agalactiae

\begin{tabular}{|c|c|c|c|c|c|c|c|c|c|c|c|}
\hline \multirow{2}{*}{ Sampling } & \multirow{2}{*}{$\begin{array}{l}\text { Perlakuan } \\
\text { (Treatment) }\end{array}$} & \multicolumn{10}{|c|}{ Pengenceran ke- (Dilution number -) } \\
\hline & & 0 & 2 & 4 & 8 & 16 & 32 & 64 & 128 & 256 & 512 \\
\hline Minggu 0 & Pooled & + & + & + & \pm & & & & & & \\
\hline \multirow{4}{*}{$\begin{array}{l}\text { Minggu I } \\
\text { (First week) }\end{array}$} & $A$ & + & + & + & + & \pm & & & & & \\
\hline & B & + & + & + & + & + & \pm & & & & \\
\hline & C & + & + & + & + & + & \pm & & & & \\
\hline & $\mathrm{D}$ & + & + & + & + & \pm & & & & & \\
\hline \multirow{4}{*}{$\begin{array}{l}\text { Minggu II } \\
\text { (Second } \\
\text { week) }\end{array}$} & A & + & + & + & + & + & + & + & + & + & \pm \\
\hline & B & + & + & + & + & + & + & + & \pm & & \\
\hline & C & + & + & + & + & + & + & + & + & \pm & \\
\hline & $\mathrm{D}$ & + & + & + & + & \pm & & & & & \\
\hline \multirow{4}{*}{$\begin{array}{l}\text { Minggu III } \\
\text { (Third week) }\end{array}$} & $A$ & + & + & + & + & + & + & + & + & + & \pm \\
\hline & B & + & + & + & + & + & + & + & \pm & & \\
\hline & $C$ & + & + & + & + & + & + & + & + & \pm & \\
\hline & $\mathrm{D}$ & + & + & + & + & \pm & & & & & \\
\hline
\end{tabular}

Keterangan (Note):

$\mathrm{A}=$ Formalin killed, $\mathrm{B}=$ Heat killed, $\mathrm{C}=$ Sonicated kill, dan $\mathrm{D}=$ Kontrol 
Tabel 4. Nilai sintasan (\%) ikan uji pada akhir proses uji tantang terhadap Streptococcus agalactiae serta nilai relative percent survival (RPS)

Table 4. Survival rate values of fish at last challenge test to Streptococcus agalactiae and relative percentage survival values (RPS)

\begin{tabular}{lcc}
\hline \multicolumn{1}{c}{$\begin{array}{c}\text { Perlakuan } \\
\text { Treatment }\end{array}$} & $\begin{array}{c}\text { Sintasan } \\
\text { Survival rate }\end{array}$ & RPS \\
\hline A (Formalin killed) & 15.57 & 13.6 \\
B (Heat killed) & 4.47 & 2.3 \\
C (Sonicated killed) & 8.93 & 6.8 \\
D (Control) & 2.23 & - \\
\hline
\end{tabular}

dibandingkan dengan teknik inaktivasi lainnya; hal ini terlihat dari nilai titer antibodi serta tingkat sintasan hidup ikan uji yang lebih tinggi dibandingkan dengan kelompok lainnya.

\section{Pembahasan}

Keunggulan ikan nila yang kompetitif dan komparatif telah menjadikan dirinya sebagai primadona budidaya air tawar yang diharapkan mampu meningkatkan produksi perikanan nasional, kesejahteraan, serta konsumsi protein hewani asal ikan. Pembudidayaan ikan nila di Indonesia dilakukan dalam berbagai sistem (ekstensif, semi-intensif, intensif, monokultur, polikultur, monoseks kultur, dll.) tergantung pada kondisi pembudidaya, karakteristik lokasi, kondisi lingkungan, faktor sosial ekonomi, penguasaan teknologi, dan potensi pasar. Selama ini ikan nila diyakini sebagai salah satu ikan budidaya yang tahan terhadap penyakit, namun indikasi ini sudah mulai pudar karena sering dilaporkan adanya kasus penyakit pada budidaya ikan nila, terutama yang disebabkan oleh golongan bakteri. Berdasarkan sampel yang dikirim oleh pembudidaya ikan ke Laboratorium Kesehatan dan Patologi Ikan BRPBAT, secara umum dapat dikatakan bahwa Streptococcus spp. merupakan bakteri yang paling sering teridentifikasi dari kasus penyakit pada ikan nila; sedangkan Flavobacterium columnare umumnya menginfeksi ikan nila pada stadia awal.

Jenis bakteri yang terisolasi dari kasus penyakit streptococcosis pada budidaya ikan nila di lokasi pengambilan sampel pada riset ini didominasi oleh Streptococcus agalactiae
$(12 / 15 \approx 80 \%)$ dibandingkan dengan S. iniae $(3 / 15 \approx 20 \%)$. Keragaan yang hampir sama dilaporkan dari monitoring yang dilakukan oleh Labrie et al. (2007) dari kasus streptococcosis pada ikan nila, yaitu S. agalactiae (219/ $294 \approx 74,5 \%$ ) dan S. iniae (75/294 $\approx 25,5 \%)$ dari 36 lokasi di wilayah Asia. Sedangkan Supriyadi \& Bastiawan (2002) melaporkan hasil monitoring penyakit streptococcosis pada ikan nila di wilayah Jawa Barat dan Banten hanya ditemukan adanya infeksi S. inae, dan tidak ditemukan adanya infeksi S. agalactiae tetapi Supriyadi et al. (2005) menemukan S. agalactiae dari Cirata dan Gajah Mungkur.

Pemeriksaan secara mikroskopis terhadap 20 ekor ikan uji untuk mengetahui keberadaan infestasi eksternal parasit diketahui bahwa populasi ikan uji relatif bersih dari infestasi parasit. Hasil isolasi bakteri target (Streptococcus spp.) uji juga menunjukkan hasil negatif, sehingga populasi ikan uji diasumsikan sebagai populasi SPF terhadap Streptococcus spp., dan populasi tersebut telah memenuhi persyaratan untuk digunakan sebagai ikan uji dalam kegiatan riset ini.

Evaluasi potensi patogenik kelima belas isolat menunjukkan bahwa seluruh isolat bersifat patogenik, menimbulkan perubahan secara klinis serta mengakibatkan kematian ikan uji; bahkan sebagian besar di antaranya bersifat akut. Yanong \& Floyd (2002) menyatakan bahwa infeksi Streptococcus spp. pada ikan nila dapat bersifat akut yang mengakibatkan kematian massal (>50\%) dalam tempo 3-7 hari, atau kematian berpola kronik yang persisten selama beberapa minggu. Pola yang sama terjadi pula pada riset ini, meskipun dapat dikatakan bahwa infeksi S. agalactiae umumnya lebih bersifat akut; sedangkan $S$. iniae umumnya bersifat kronik, kecuali isolat N2O.

Penyakit "syndrome meningoencephalitis and panophthalmitis" merupakan nama lain untuk streptococcosis pada ikan, dan penyakit ini nampaknya berpotensi sebagai salah satu kendala yang serius dalam program intensifikasi ikan nila. Bakteri Streptococcus spp. yang berukuran sangat kecil (diameter rata-rata $1 \mathrm{~mm}$ ) adalah bakteri gram positif yang memiliki outer membrane sel (OTS) cukup tebal dan diselimuti oleh fibrils yang memiliki potensi toksik terhadap inang. Selain itu, kelompok bakteri ini mampu hidup di sel makrofag yang merupakan komponen penting dalam sistem kekebalan tubuh ikan, baik spesifik maupun non spesifik. Sehingga tidak 
mengherankan apabila Clark et al. (1999) menyatakan bahwa penggunaan antibiotik untuk melawan infeksi kelompok bakteri ini kurang berhasil, karena dibutuhkan dosis yang cukup tinggi untuk melawan sel bakteri yang berada di dalam sel makrofag; namun penerapan dosis tersebut juga akan mematikan sel makrofag sehingga sistem kekebalan tubuh inang akan menurun drastis.

Secara matematis, nilai $\mathrm{LD}_{50}$ pada jumlah bakteri paling rendah dimiliki oleh bakteri $S$. agalactiae dengan kode isolate N4M yaitu sebesar $6,44 \times 10^{2} \mathrm{cfu}$ ini artinya bahwa bakteri tersebut digolongkan pada golongan patogenitas tinggi, dan nilai $\mathrm{LD}_{50}$ terbesar dimiliki oleh bakteri $S$. iniae dengan kode isolat $\mathrm{N} 2 \mathrm{O}$ yaitu sebesar $8,3 \times 10^{5} \mathrm{cfu}$. Nilai LD $_{50}$ yang diperoleh pada riset ini jauh lebih rendah daripada yang diperoleh Al-Harbi (1996) yang melakukan uji kerentanan beberapa strain ikan nila terhadap infeksi Streptococcus spp., dan diperoleh nilai $\mathrm{LD}_{50}$ terrendah sebesar $2,8 \times$ $10^{5} \mathrm{cfu}$, dan nilai tertinggi adalah $9,2 \times 10^{7} \mathrm{cfu}$ per ekor ikan. Rendahnya nilai LD $_{50}$ mengindikasikan bahwa isolat bakteri tersebut memiliki potensi patogenik yang lebih tinggi, terlebih lagi untuk isolat N4M. Secara teoritis dapat diprediksi bahwa apabila dalam suatu populasi ikan nila berukuran \pm 15 gram/ekor, dan masing-masing ekor ikan terinfeksi oleh 500-1.000 sel bakteri S. agalactiae (N4M), maka hanya dalam periode 5 hari ( 120 jam) akan mengakibatkan kematian $850 \%$ dari total populasi.

Nilai titer antibodi dalam serum darah ikan uji yang diberi vaksin melalui penyuntikan dengan sediaan vaksin yang diinaktivasi dengan teknik berbeda memperlihatkan bahwa sediaan vaksin yang diinaktivasi dengan formalin memberikan nilai titer antibodi yang relatif lebih tinggi mulai minggu ke-2 dibandingkan dengan teknik inaktivasi lainnya. Paramater lain yang sinergis dengan indikasi ini adalah nilai rataan persen mortalitas kumulatif pasca uji tantang terhadap isolat bakteri homolog. Pada kelompok ikan yang diberi vaksin yang diinaktivasi dengan formalin juga memberikan level proteksi yang relatif lebih baik dibandingkan dengan teknik inaktivasi lainnya.

Fenomena ini terjadi diduga karena proses pemanasan (heat killed vaccine) pada suhu $100^{\circ} \mathrm{C}$ terhadap sediaan baku vaksin dapat merusak struktur dasar antigen (denaturasi) serta koagulasi protein antigen yang merupakan material yang bersifat antigenik. Secara hipotetik, inaktivasi vaksin melalui sonikasi (sonicated vaccine) diharapkan dapat memberikan hasil yang lebih baik karena fraksifraksi sel bakteri akan terpecah sehingga diyakini akan mempermudah sel-sel fungsional untuk mengenalinya. Namun berdasarkan hasil uji viabilitas, masih ditemukan adanya pertumbuhan koloni bakteri; sehingga vaksin tersebut tidak aman terhadap ikan uji. Hal ini terlihat dari tingginya mortalitas ikan uji dari kelompok perlakuan ini selama periode induksi kekebalan yang ditetapkan selama 3 minggu.

Nilai titer antibodi yang teramati (reaksi antigen-antibodi dalam bentuk aglutinasi) mengindikasikan bahwa vaksin sel utuh bakteri S. agalactiae isolat N4M memiliki potensi imunogenik. Namun, secara sederhana dapat dikatakan bahwa antibodi spesifik yang terbentuk belum mampu memberikan level proteksi yang baik, karena nilai RPS masih jauh di bawah 50\%. Klesius et al. (1999) melakukan vaksinasi pada ikan nila dengan vaksin S. inae, dan tidak diperoleh hasil yang memuaskan setelah diuji tantang dengan bakteri homolog; dimana mortalitas mencapai $100 \%$ pada kelompok ikan setelah hari ke-4 pasca uji tantang, sedangkan tingkat mortalitas yang sama pada kelompok ikan kontrol baru terjadi pada hari ke-1 1. Sedangkan Pasnik et al. (2005) berhasil membuat vaksin anti $S$. agalactiae yang cukup protektif. Sediaan vaksin tersebut berupa sel utuh yang diinaktivais dengan formalin (formalin killed vaccine) dan extracellular products (ECP) dari $S$. agalactiae. Selanjutnya dinyatakan bahwa ECP $S$. agalactiae mengandung antigen yang berbobot molekul $55 \mathrm{kDa}$, yang dalam hal ini telah diketahui sebagai antigen potensial untuk memproduksi antibodi dan proteksi terhadap bakteri tersebut.

Dari kajian ini secara eksplisit mengisyaratkan adanya dugaan bahwa materi imogenik berada pada sel bakteri yang masih relatif utuh, dan konsentrasi formalin yang digunakan belum optimal, sehingga berpengaruh terhadap keutuhan struktur dan/ atau pelepasan material imunogenik dari sel bakteri. Selain itu, karakteristik biologis dari bakteri S. agalactiae yang menginfeksi ikan nila belum sepenuhnya terungkap, termasuk faktor-faktor lingkungan yang permisif dan non-permisif. 


\section{KESIMPULAN DAN SARAN}

\section{Kesimpulan}

1. Karakterisasi secara biokimia terhadap 15 isolat bakteri Streptococcus spp. diketahui sebanyak 12 isolat (80\%) adalah $S$. agalactiae dan 3 isolat (20\%) adalah S. iniae. Koch's Postulate terhadap seluruh isolat membuktikan bahwa semuanya memiliki potensi patogenik terhadap ikan nila. Konfirmasi taksonomis hingga level spesies isolat bakteri S. agalactiae dengan teknik Polymerase Chain Reaction (PCR) diperoleh hasil positif.

2. Dari 6 isolat hasil penapisan awal yang terdiri atas 5 isolat bakteri $S$. agalactiae (N3M, N4M, N14G, N17O, NK1) dan 1 isolat bakteri S. iniae (N2O); bakteri S. agalactiae (N4M) memiliki nilai $\mathrm{LD}_{50}$ terkecil yaitu 6,44 $\times 10^{2} \mathrm{cfu}$, dan nilai $\mathrm{LD}_{50}$ terbesar dimiliki oleh bakteri S. iniae dengan kode isolat $\mathrm{N} 2 \mathrm{O}$ yaitu sebesar $8,3 \times 10^{5} \mathrm{cfu}$.

3. Isolat bakteri N4M bersifat virulensi tinggi dan dapat memiliki tingkat virulensi yang paling tinggi sehingga digunakan sumber antigen dalam pembuatan vaksin anti streptococcosis.

4. Nilai titer antibodi dan sintasan tertinggi diperoleh pada kelompok ikan yang divaksin dengan formalin killed vaccine dibandingkan dengan teknik inaktivasi lainnya (heat killed vaccine dan sonicated vaccine). Meskipun demikian, secara umum dapat disimpulkan bahwa antibodi yang terbentuk masih jauh dari level proteksi, karena nilai RPS masih di bawah 50\%.

\section{Saran}

Perlu kajian yang lebih detail terhadap efektivitas berbagai sediaan, teknik inaktivasi dan aplikasi vaksin; serta ekplorasi unsur imunogenik dari sel bakteri Streptococcus agalactiae, sehingga dapat dikembangkan sediaan vaksin yang lebih tepat, efektif, dan protektif.

\section{UCAPAN TERIMA KASIH}

- Riset ini dibiayai oleh DIPA 2009 Balai Riset Perikanan Budidaya Air Tawar, Bogor.

- Penulis mengucapkan terima kepada Saudara Ahmad Wahyudi, Mikdarullah, Edy Farid, dan Bambang Priadi atas bantuannya selama pelaksanaan kegiatan riset ini.

\section{DAFTAR ACUAN}

Al-Harbi, A.H. 1996. Susceptibility of five species of Tilapia to Streptococcus spp. Asian Fisheries Science. Asian Fisheries Society, Manila, Philippines, 9: 177-181.

Austin, B. \& Austin, D.A. 2001. Chapter 2Characteristics of the diseases. In Bacterial Pathogens: Diseases of Farmed and Wild Fish, p. 13-15.

Berridge, B.R., Bercovier, H., \& Frelier, P.F. 2001. $S$. agalactiae and $S$. difficile $16 \mathrm{~S}-23 \mathrm{~S}$ Intergenic rDNA Genetic Homogeneity and Species-Spesific PCR. Vet. Microbipl., 78: 165-173.

Clark, J.S., Paller, B., \& Smith, P.D. 1999. Prevention of streptococcus in tilapia by vaccination : the Philippine experience. Journal of Fish Diseases, 27: 144-150.

Ellis, A.E. 1998. Fish Vaccination. Academic Press Limited, London, 255 pp.

Ferguson, H.W., Morales, J.A., \& Ostland, V.E. 1994. Streptococcosis in aquarium fish, Diseases of Aquatic Organisms, 19(1): 1-6.

Frerichs, G..N. \& Millar, S.D. 1993. Manual for the Isolation and Identification of Fish Bacterial Pathogens. Pisces Press. Stirling, $60 \mathrm{pp}$.

Inglis, V., Roberts, R.J., \& Bromage, N.R. 1993. Chapter 12, Streptococcal Infections. In Bacterial Diseases of Fish, Halsted Press, John Wiley \& Sons, Inc., NY, p. 196-97.

Klesius, P.H., Shoemaker, C.A., \& Evans, J.J. 1999. Efficacy of a killed Streptococcus iniae vaccine in tilapia \{Oreochromis niloticus). Bull. Eur Ass Fish Pathol., 19(1): 38-41.

Labrie, L., Joseph, N., Komar, C., \& Sheehan, B. 2007. Bacterial Diseases of Finfish in the South East Asian Region. Intervet Aquatic Animal Health Newsletter. 15 November 2007. Singapore, p. 11-12.

Pasnik, D.J., Evans, J.J., Panangala, V.S., Klesius, P.H., Shelby, R.A., \& Shoemaker, C.A. 2005. Antigenicity of Streptococcus agalactiae extracellular products and vaccine efficacy. In Journal of Fish Diseases, 28(4): 205 212.

Roberson, B.S. 1990. Bacterial Agglutination dalam Fish Immunology Technical Communication No. 1 edited by Stolen, J.S., T.C. Fletcher, D.P. Anderson, B.S. Roberson and W.B. van Muiswinkel. SOS Publications. Fair Haven, N.J., 197 pp.

Shoemaker, C. \& Klesius, P. 1997. Streptococ- 
cal Disease Problems and Control: A Review. In Tilapia Aquaculture, K. Fitzsimmons, Editor, NREAES 106, Ithaca, NY, 2: 671-80.

Supriyadi, H. \& Bastiawan, D. 2002. Karakterisasi dan identifikasi patogen penyebab penyakit streptococciasis pada ikan air tawar yang dibudidayakan. Laporan Teknis Proyek Riset Perikanan Budidaya Air Tawar. Balai Riset Perikanan Budidaya Air Tawar. (Tidak dipublikasikan).

Supriyadi, H., Widiyati, A., Sunarto, A., \& Prihadi, T.H. 2005. Keragaan penyakit bakterial ikan nila (O. Niloticus), pada KJA di lokasi berbeda, J. Pen. Perik. Indonesia, 11 (7): 35-46.
Taukhid, Komarudin, O., Supriyadi, H., \& Bastiawan, D. 2005. Strategi pengendalian penyakit pada budidaya ikan air tawar. Serial Bunga Rampai: Strategi Pengelolaan dan Pengendalian Penyakit KHV, suatu upaya pemecahan dalam pembudidayaan ikan air tawar. Pusat Riset Perikanan Budidaya, Badan Riset Kelautan dan Perikanan, Departemen Kelautan dan Perikanan, hlm. 17-30.

Yanong, R.P.E. \& Floyd, R.F. 2002. Streptococcal infection of fish. Circular FA057. Department of Fisheries and Aquatic Sciences, Florida Cooperative Extension Service, Institute of Food and Agricultural Sciences, University of Florida. 